\title{
Behaviour as part of ecological adaptation
}

\author{
In situ studies in the coral reef
}

\author{
H. W. FRICKE \\ Max-Planck-Institut für Verbaltensphysiologie (Abteilung Lorenz); \\ Seereiesen und Erling-Andechs, Federal Republic of Germany
}

\begin{abstract}
KURZFASSUNG: Verhalten als Teil ökologischer Anpassung. In-situ-Untersuchungen im Korallenriff. Der Einfluß des Lebensraumes als Evolutionsfaktor des Verhaltens läßt sich durch Artenvergleich erschließen. Verhaltensweisen sind Teil der ökologischen Anpassung. Nicht verwandte Tiere, die in ähnlichen Biotopen leben, zeigen oft Verhaltenskonvergenzen; verwand te Tiere in unterschiedlichen Biotopen dagegen Verhaltensdivergenzen. Im Korallenriff wurden analoge und homologe Verhaltensweisen an den Funktionskreisen Nahrungserwerb (Planktonfang bei Seeanemonen, kriechenden Kammquallen, Schlangensternen und Röhrenaalen), Beutefang und Feindvermeidung (bei einigen benthonischen Invertebraten) und Sozialverhalten (bei Korallenbarschen) untersucht. Auch Sozialstrukturen sind ökologische Anpassungen. Monogamie und Plakatfarben der im Riff besonders zahlreich vertretenen Schmetterlingsfische werden als Fortpflanzungsisolationsmechanismen interpretiert. Sie ermöglichen das Nebeneinander vieler sympatrischer Arten.
\end{abstract}

\section{INTRODUCTION}

The environment as a selection factor, and thus one which influences an animal's behaviour, has recently reached importance in modern ethology. Behaviour patterns develop with time and are based on the same evolutionary mechanisms as anatomical structures (WICKLER 1959, 1961, 1967, 1971). An organism is adapted to its special environment with regard to body structure, as well as physiological and behavioural characteristics. Adaptations are properties of an organism which ensure its survival, both at the individual and at the population level (e.g. WrCKLER 1971). Behavioural adaptations to ecological factors can be demonstrated without answering the question as to how they came about. Similarities can be found in taxonomically unrelated animals inhabiting the same environment and, on the other hand, vast differences can be shown to exist between closely related species living in different biotopes. Such divergence in adaptation has obviously come about through environmental influences. To study ecological adaptation, it is necessary to compare large numbers of species and, through this, to draw general conclusions ("Reihenmethode of REMANE").

Structure, physiology and behaviour should be considered simultaneously, since adaptation to a new ecological niche involves the entire gene pool of the organism. It 
can be shown, however, that behaviour is the most flexible of the three aspects and hence is of considerable importance as an evolutionary pace-maker. Changes in behaviour frequently precede changes in structure and physiology during adaptive evolution. WICKLER (1971) states that behaviour is the most flexible property of an animal, and the more variable the behavioural inventory, the more adaptive the animal itself.

An organism is in a state of continual flux with its environment (inanimate surroundings, food, enemies, non-conspecifics and conspecifics). Each of the different environmental entities can exert a selective effect.

Ecology-oriented ethology has, thus far, concentrated on the adaptive value of behavioural patterns with regard to living space, establishment of territories, prey capture, and enemy avoidance. Recently, however, social behaviour and social structure have also been considered part of an organism's ecological adaptations.

Marine ethology is still a young field of research; adaptive values regarding the behaviour of aquatic animals have rarely been investigated. Owing to this and due to ladk of observational material, comparative analyses can hardly be attempted.

I should like to present here an outline of the in situ studies which I have conducted during the last few years; they are mainly concerned with the adaptation of invertebrate and vertebrate animals to the coral reef environment. Bearing in mind the topic of this International Helgoland Symposium, the methods employed in these underwater investigations will also be considered. I shall concentrate on feeding, responses to enemies and prey, and on social behaviour and social structure, and attempt to demonstrate divergences in adaptation, which will necessitate on occasion that organ structures also be included in the discussion.

\section{FEEDING ADAPTATIONS}

Plankton plays an extremely important role in the nourishment of reef inhabitants; this has been proved by numerous studies. Plankton drifts in water currents. Numerous benthonic animals have become specialised in fishing plankton from water currents. Many - such as the Porifera and Polychaeta - produce their own currents in order to obtain planktonic food. Others simply extend their plankton-capturing structures into the prevailing current. These passive plankton feeders have similar capturing structures and behaviour patterns independent of their taxonomic relationships. For example, the nocturnal sea anemone Alicia zanzibarica which inhabits the Red Sea (Fig. 1) extends its long tentacles into the current at nightfall. Drifting plankton contacts the tentacles, whereupon these contract immediately and bend towards the mouth. Such behavioural sequence is known from many other sea anemones (Fig. 1). The creeping ctenophore, Bentboplana meteoris inhabits sandy, current-washed sea bottoms in the western Indian Ocean; a related species, Coelopland bannwartbi lives on the spines of the sea urchin Diadema setosum; Coeloplana wennenbergii, C. lineoolata and C. punctata live beneath the umbrellas of the octocorallian Sarcophyton sp. All these benthonic ctenophores are nocturnal (FrICKE 1970a, b). Their adhesive tentacles sometimes extend over more than $1 \mathrm{~m}$ into the water current (Fig. 2). Plankton impinging on these remains attaches and causes tentacle contraction, which draws the 

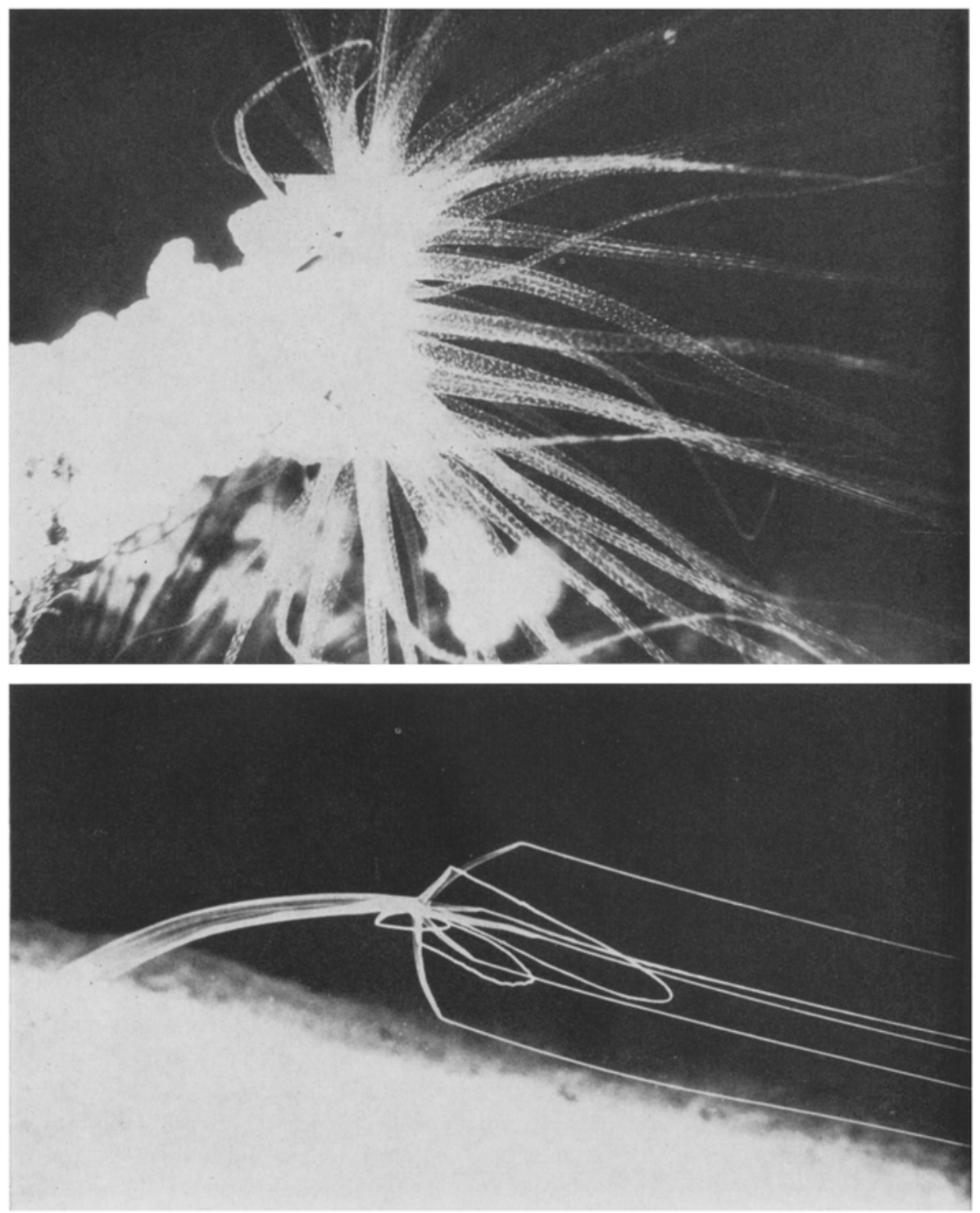

Fig. 1: Filtering of water currents is a widely distributed phenomenon amongst nocturnal sea anemones. Above: Alicia sansibarensis; below: an unidentified species

prey to the tentacular pouches. The sea anemones and ctenophores have both extended their prey-capture devices and the movements which they perform during feeding are also very similar. These animals could be termed "lime twig hunters". Their nocturnal activity period is probably an adaptation to the increase in plankton abundance in the reef area during the night. 


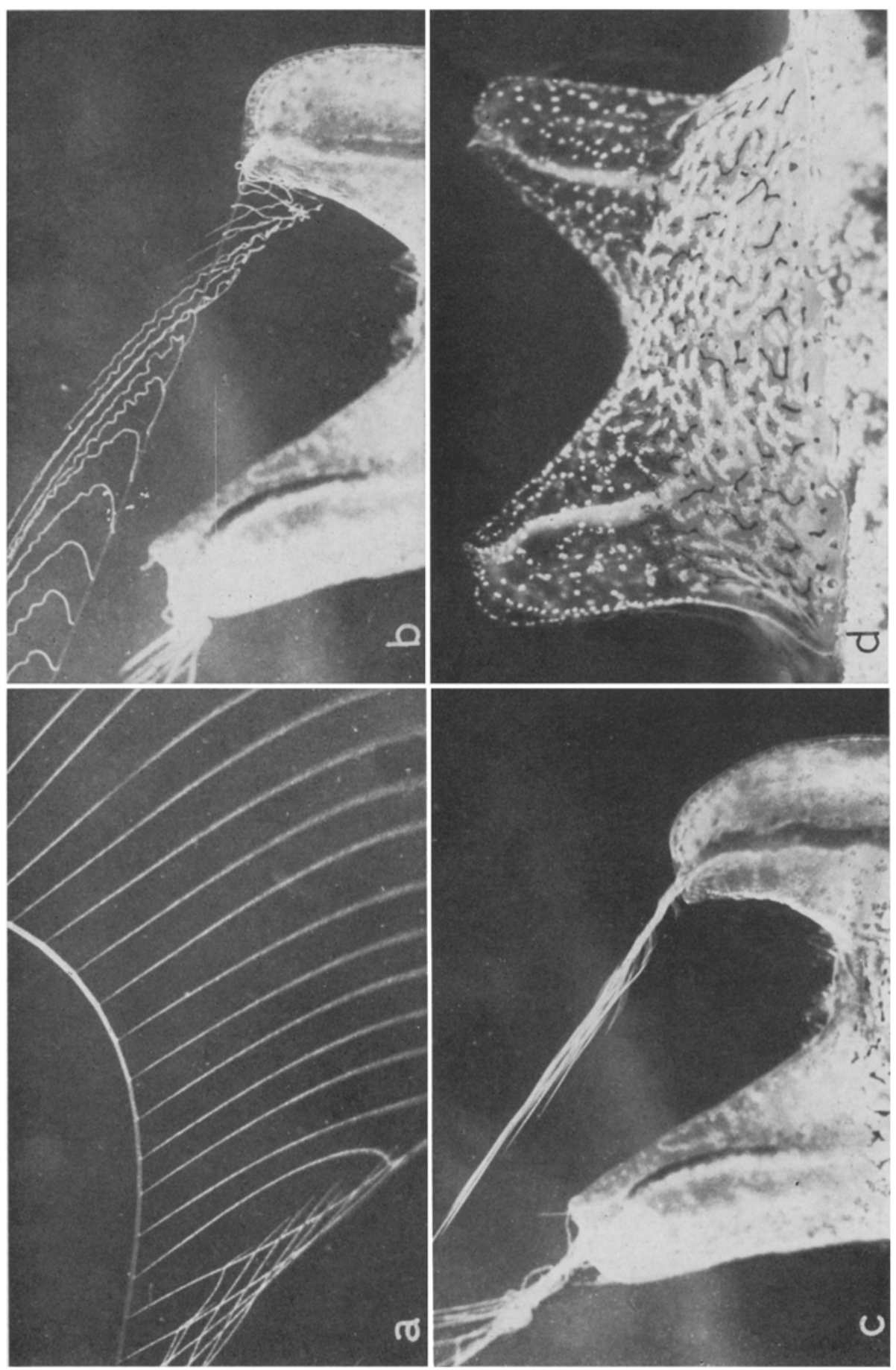

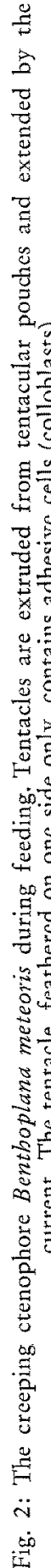


The sea anemones and ctenophores described inhabit areas of current flow and show specific individual locality behaviour ("Standortverhalten"). Sea anemones are more or less stationary but Benthoplana meteoris can actively swim away backwards under unfavourable conditions. Coeloplana sp. select high positions in order to be able
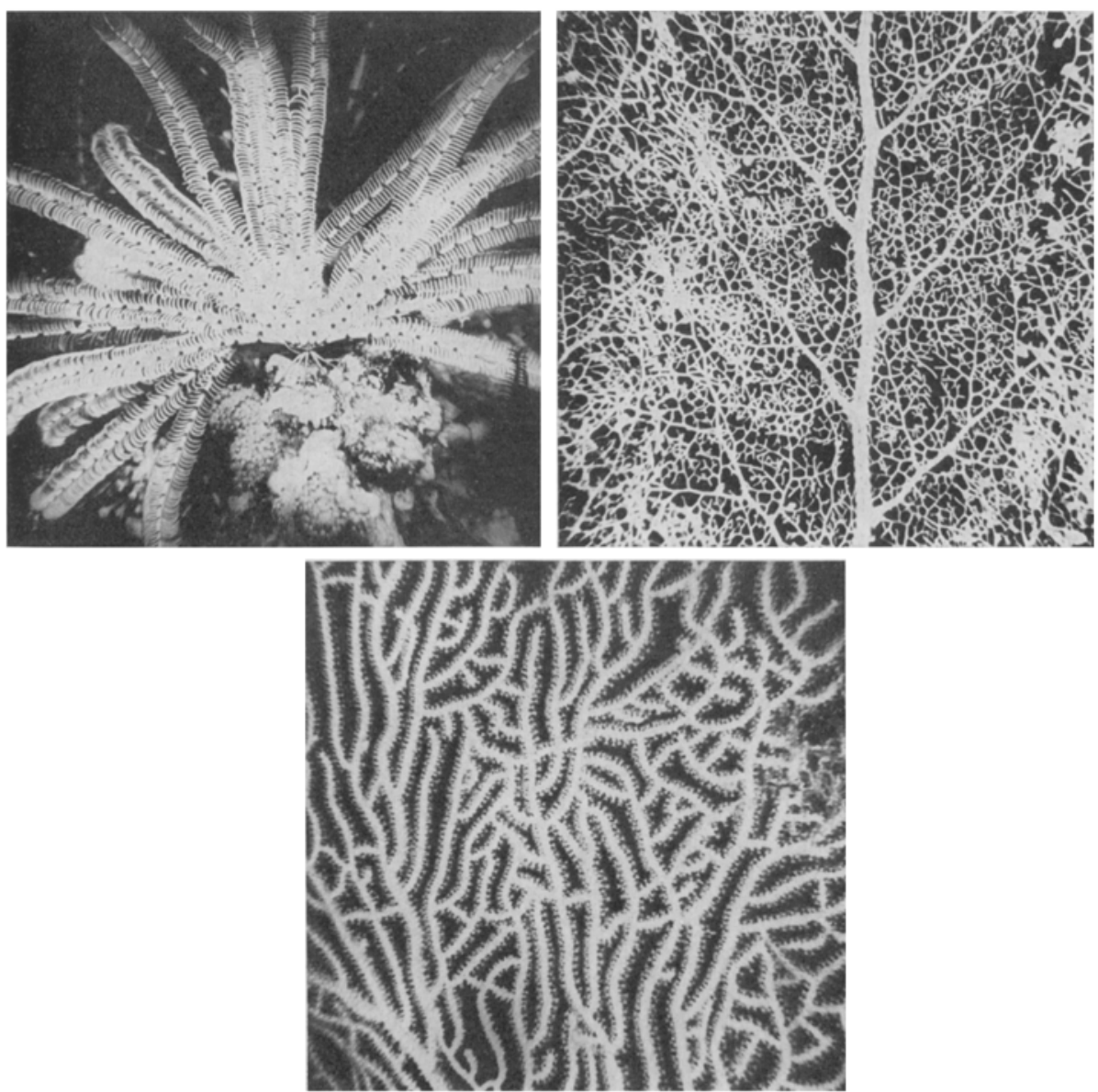

Fig. 3: Convergent development causes similar behaviour patterns and prey-capture organs. Adaptations in plankton capture from the water current. Left: nocturnal filtering comatulid crinoid; right: portion of filter fan of the nocturnal basket star Astroboa nuda; below: portion of a gorgonid filter fan. Food-holding organs and food-transport methods differ considerably between these animals (ambulacral grooves in crinoids, capturing hooks in the basket stars, tentacles with nematocysts in the gorgonids)

to extend their tentacles to the maximum. Although prey-capture devices on the tentacles differ (nematocysts in sea anemones and colloblasts in ctenophores), activity periods and prey-capture behaviour are similar, even in detail. These are examples of convergent developments which may be interpreted as adaptation to ecological factors; 
they are also present in radially symmetrical plankton feeders. MAGNus (1963a, 1964a, b) discovered that the comatulid crinoids Heterometra savignyi and Lamprometra sp. climb to higher levels during the night and extend their arms perpendicularly to form a flat filter fan with the aboral side of the arm towards the water current (Fig. 3). If the current direction changes, the position of the arms also changes. The basket stars
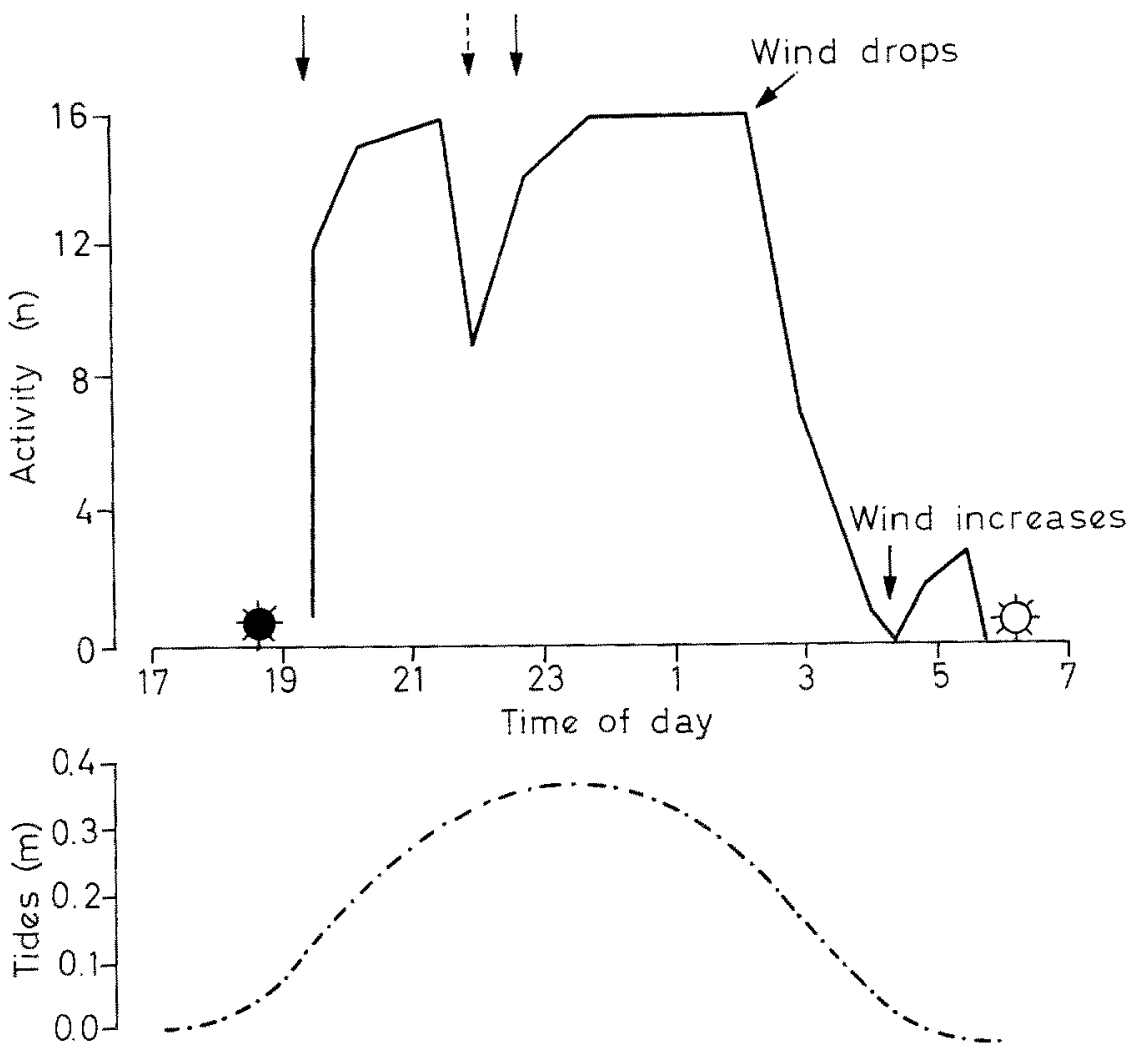

Fig. 4: Astroboa nuda from the Red Sea. Nocturnal activity related to tidal currents (lower dotted line) and currents caused by wind. The number ( $\mathrm{n}$ ) of open filter umbrellas (in a colony consisting of 16 individuals) was taken as measure of activity. Pexpendicular arrows show direction of filter-umbrella orientation. Arrow: filter umbrella points towards land; Broken arrow: umbrella points towards sea. (After Fricke 1968)

behave similarly (Davis 1966, Fricke 1966, Tsurnamal \& Marder 1966). By marking animals individually, I was able to show that these creatures return to the same location every night and move into their hiding places by day. The basket stars also change the position of their arms when the current direction changes (Fig. 4). They differ, however, from the crinoids in the manner of food transportation. Crinoids catch the plankton with their tentacles, envelop it in mucus and then transport it to the mouth along the ambulacral grooves. Basket stars capture the plankton with a complicated hook apparatus and envelop the prey with the branched tips of the arms, thus 

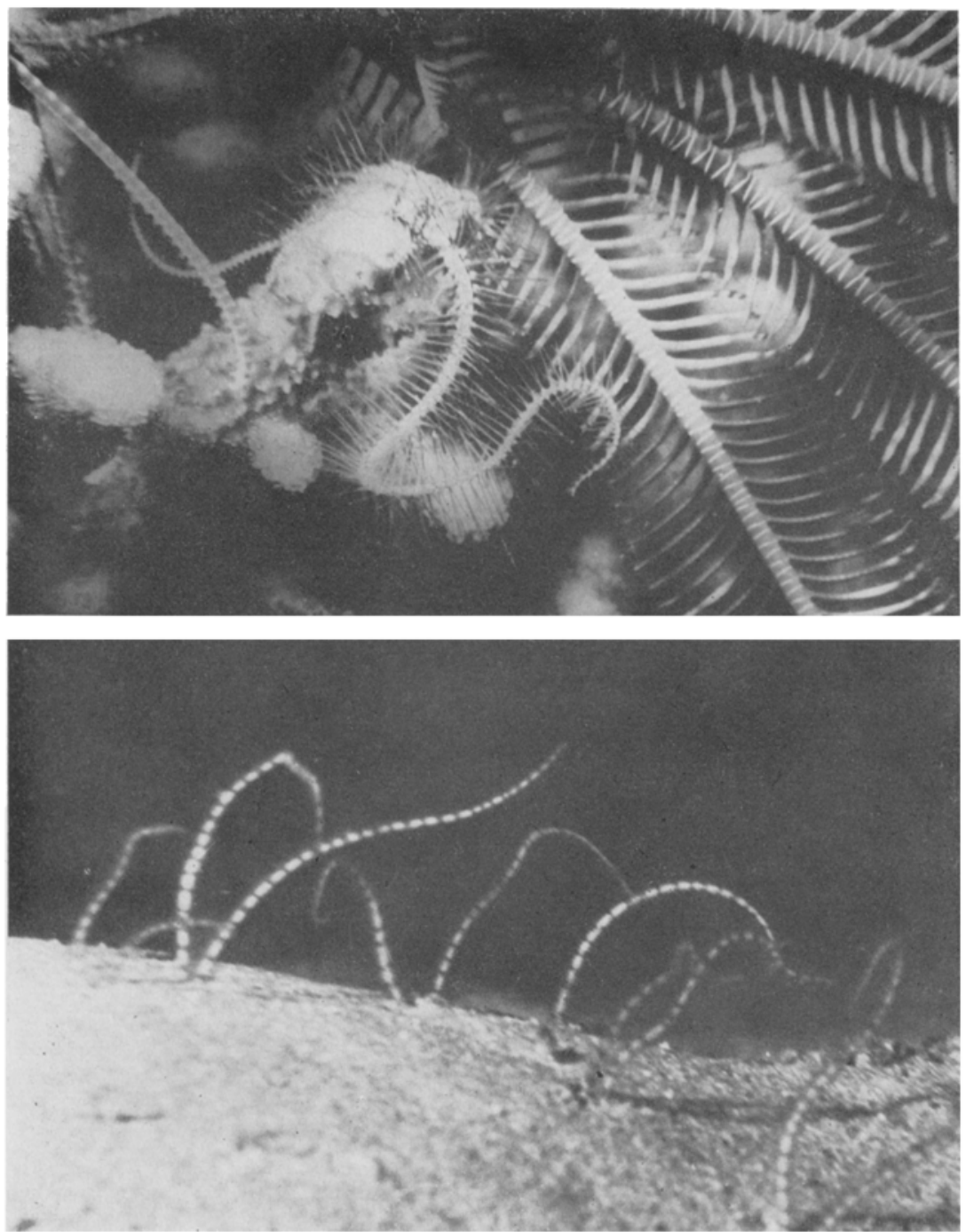

Fig. 5: Current filtering is a widely distributed and probably phylogenetically ancient behaviour pattern amongst brittle stars. Above: a nocturnal, unidentified species contracts arms to a spiral, increasing the filtration area; podia form an efficient filter comb. Below: Ampbioplus $\mathrm{n}$. sp. filters only with the tips of its more than $40 \mathrm{~cm}$ long arms. (After Fricke 1970c)

forming a nodule. At the end of the nocturnal activity period, they roll the main arms inwards in a spiral. The arm tips are then cleaned later in the jaw apparatus. Food transport and means of prey capture thus differ appreciably (FRICKE 1968).

A large number of brittle stars are also plankton feeders (Fig. 5). MaGnus (1963b) studied Ophiocoma scolopendrina, which has a tidal activity rhythm and, apart from being a current filter feeder, is also a substrate feeder. When the tide comes in, $\mathrm{O}$. sco- 


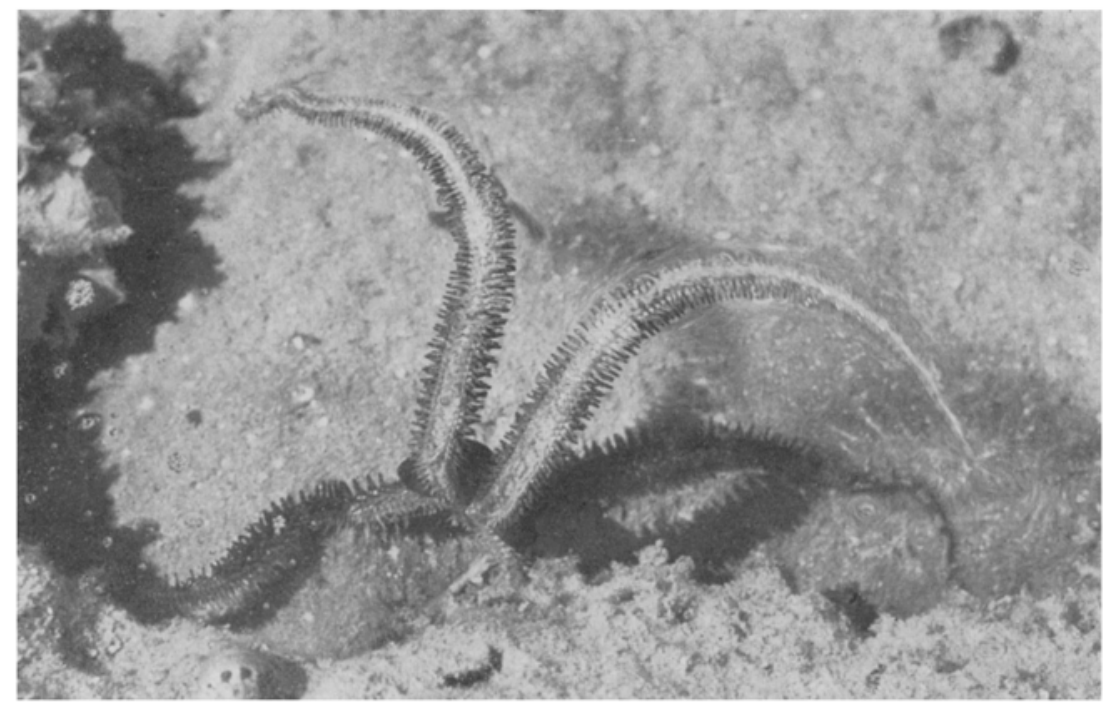

Fig. 6: Specialised food-capture behaviour represents adaptation to life in extreme habitats. Incoming tidal waters are fished by the tidally active Opbiocoma scolopendrina

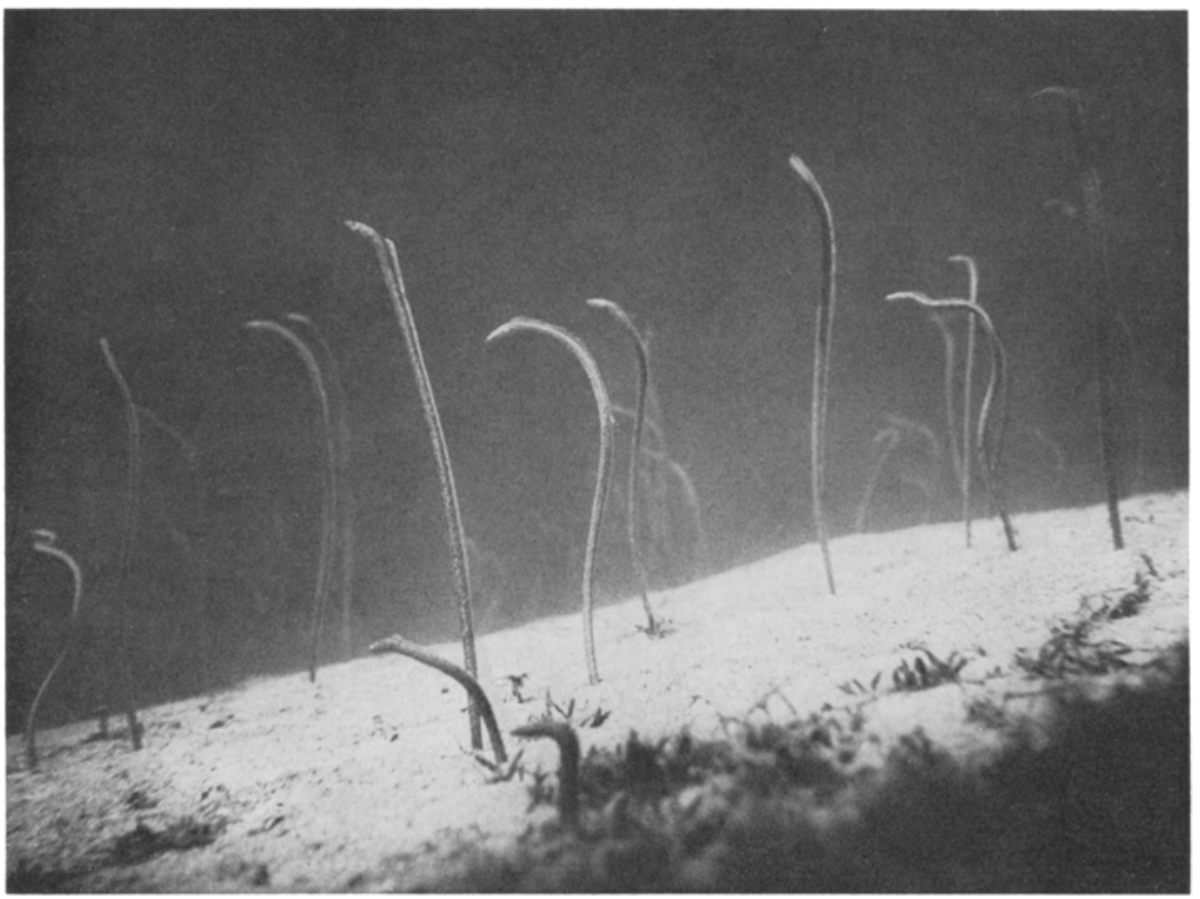

Fig. 7: Garden eels (here Gorgasia sillneri) from the Red Sea have developed a semi-sessile mode of life. This development is interpreted as adaptation to plankton feeding 
lopendrina collects fine detritus from the current employing specific arm movements (Fig. 6). This flexibility in feeding has presumably made inhabitation of the tidal zone possible. I have made similar observations on Amphioplus sp. (description in preparation by Prof. Cherbonnier), a new species from Madagascar (Fricke 1970c). Am-
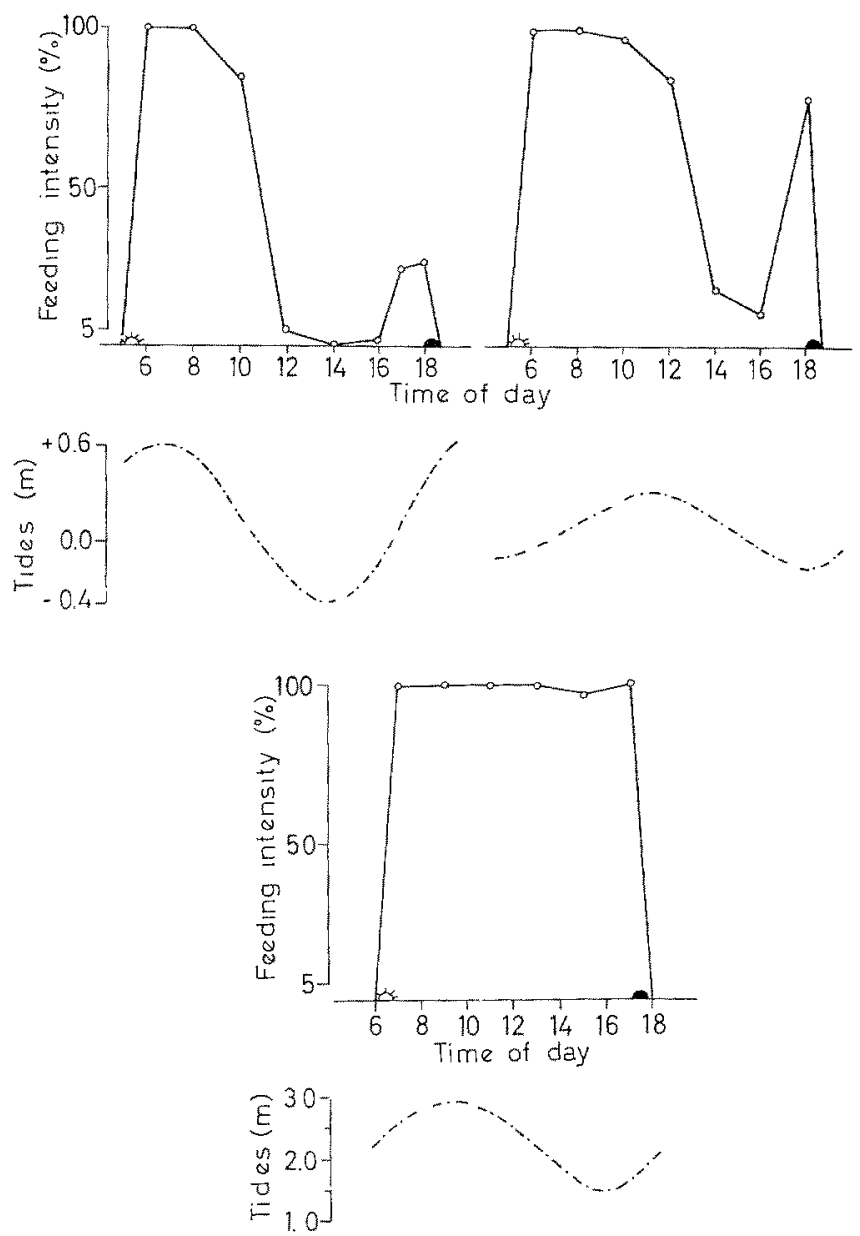

Fig. 8: Diurnal periodicity of feeding intensity in two garden eels (above: Gorgasia sillneri, below: Taenioconger bassi). Feeding intensity depends on the water current. Ordinate: feeding intensity expressed in terms of the body length visible (the hungrier the eel is, the more it emerges from its tube). Measurements were made on 25 individuals every minute for half an hour. (After Fricke 1970d)

pbioplus sp. inhabits sandy bottom areas with strong current flow and uses the tips of its arms, which can attain a length of up to $40 \mathrm{~cm}$, as filter mechanisms (Fig. 5). The podia stand almost vertical and form a filter comb. If the current direction changes, the filter comb can be turned to face it again. Arms and body disc are enclosed in a 

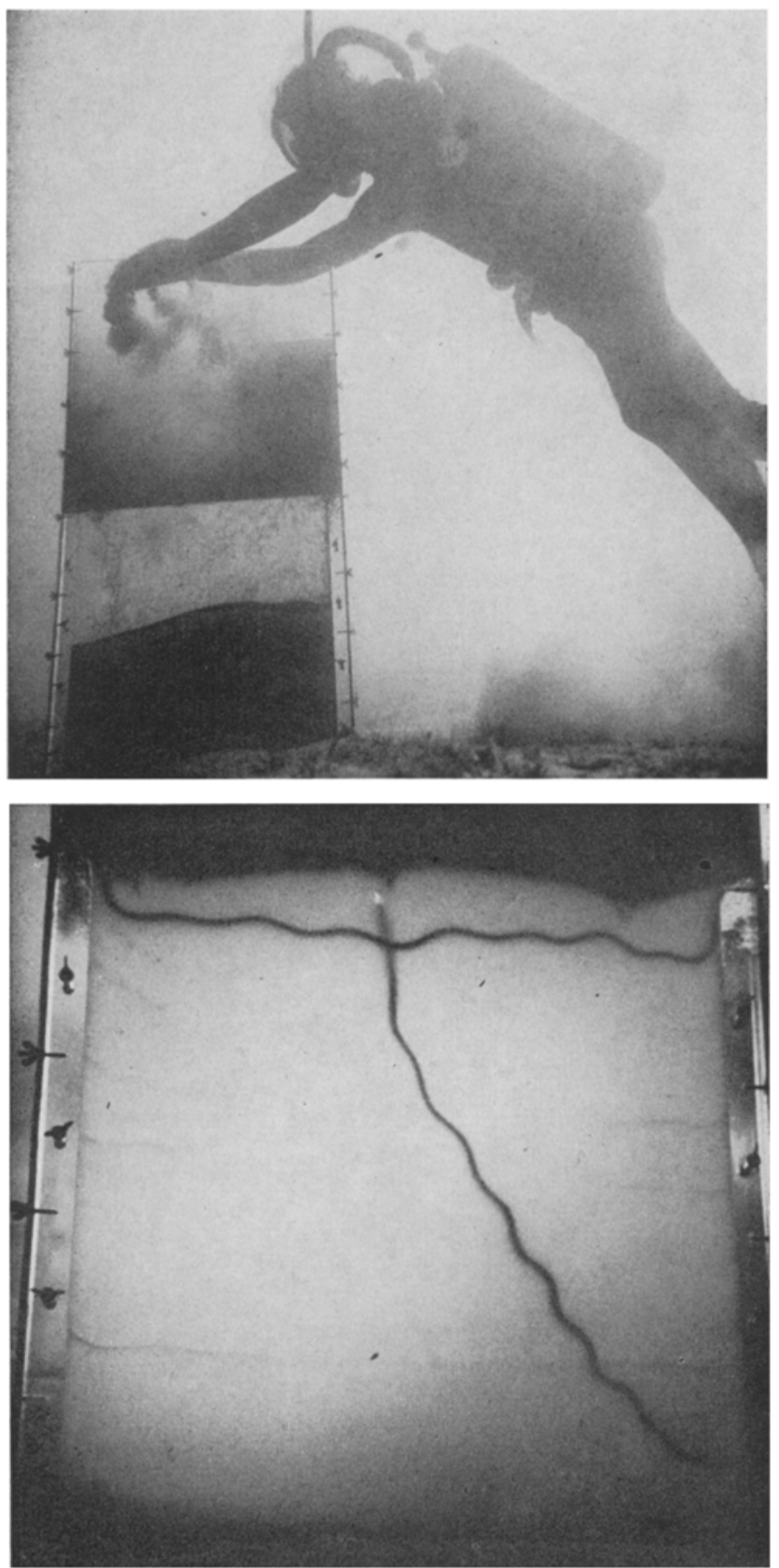

Fig. 9: Experiment to illustrate sub-sand burrowing behaviour in garden eels. Above: Experimental aquarium consisting of 2 plexiglass plates, about $1 \mathrm{~cm}$ apart; the space between is filled with sand. Below: silhouettes of 2 buried eels 
self-constructed sand tunnel during filtration, and the brittle star retreats rapidly into this tunnel in case of danger. Such current filtration in brittle stars is a common, and phylogenetically presumably old, behavioural pattern. Other methods of feeding may develop in response to special environmental circumstances. Basket stars, however, have specialised entirely in this type of feeding, even to the extent of developing new anatomical structures. Holding and transportation of prey, employed by basket stars, appear to be new phylogenetic developments.

Plankton capture from the current by "lime twigs" or filter fans occurs mainly in benthonic invertebrates. Plankton can, however, be captured by active snapping. We have observed colonies of diurnal garden eel of the genera Gorgasia, Taenioconger and Nystacichthys (CASTle 1967, Clarke 1972, Fricke 1969, 1970d, Kiausewitz \& EIBL-EIBESFELdT 1959). Their mode of life is exceptional for a vertebrate; they live in semi-sessile colonies - apparently an adaptation to capturing plankton from the current (Fig. 7). A continual current providing food may have been the decisive factor for the development of this semi-sessile behaviour, which shows analogies to that of sessile benthonic invertebrates. The garden eels focus prey binocularly before snapping at it; activity period and feeding intensity depend upon the current conditions present and thus upon the amount of food available (Fig. 8). This specialisation to feeding on plankton while remaining in a specific spot in open, sandy bottoms is unusual for marine eels; it has resulted in other behavioural and morphological changes, a few of which will be mentioned.

The eels dig tubes in the sandy substrate and cement their walls with slime. The digging behaviour was observed in a specially constructed aquarium (Fig. 9). The eel compacts its tube by patting and thrusting movements of its tail, at the same time secreting the slime. The slime is produced by a gland on the tail (FrrCke 1970d, Casimir \& Fricke 1971). We have been able to prove the existence of the slimeproducing gland histologically in each of the 3 garden eel genera investigated. In case of danger, the garden eels quickly disappear backwards into their tubes. The flight distance is relatively large and hence the eels are difficult to observe.

The observations on the representatives from all three genera indicate that they are similar in both social and non-social behaviour patterns. The homogenous environment, which reveals little fluctuation, has probably led to the development of a uniform ecotype. The example of the garden eel illustrates how specific behavioural adaptation may yield co-operative other changes in behaviour, morphology and, probably, physiology.

\section{ADAPTATIONS IN PREY CAPTURE AND ENEMY AVOIDANCE}

Benthonic reef invertebrates are a source of food for numerous fishes, and exist under continuous pressures exerted by enemies. Selective stress promotes the development of protective measures. Many reef fishes attempt to eat the zooxanthellae which occur at the mantle rims of the giant clam Tridacna sp. Rapid valve closure, however, prevents contact with such enemies. Coral polyps also withdraw into their walled exoskeleton upon a contact stimulus. Even the large sea anemones of the genera Gyrostoma, Radianthus and Stoichactis are pursued by enemies. In the Red Sea, certain 

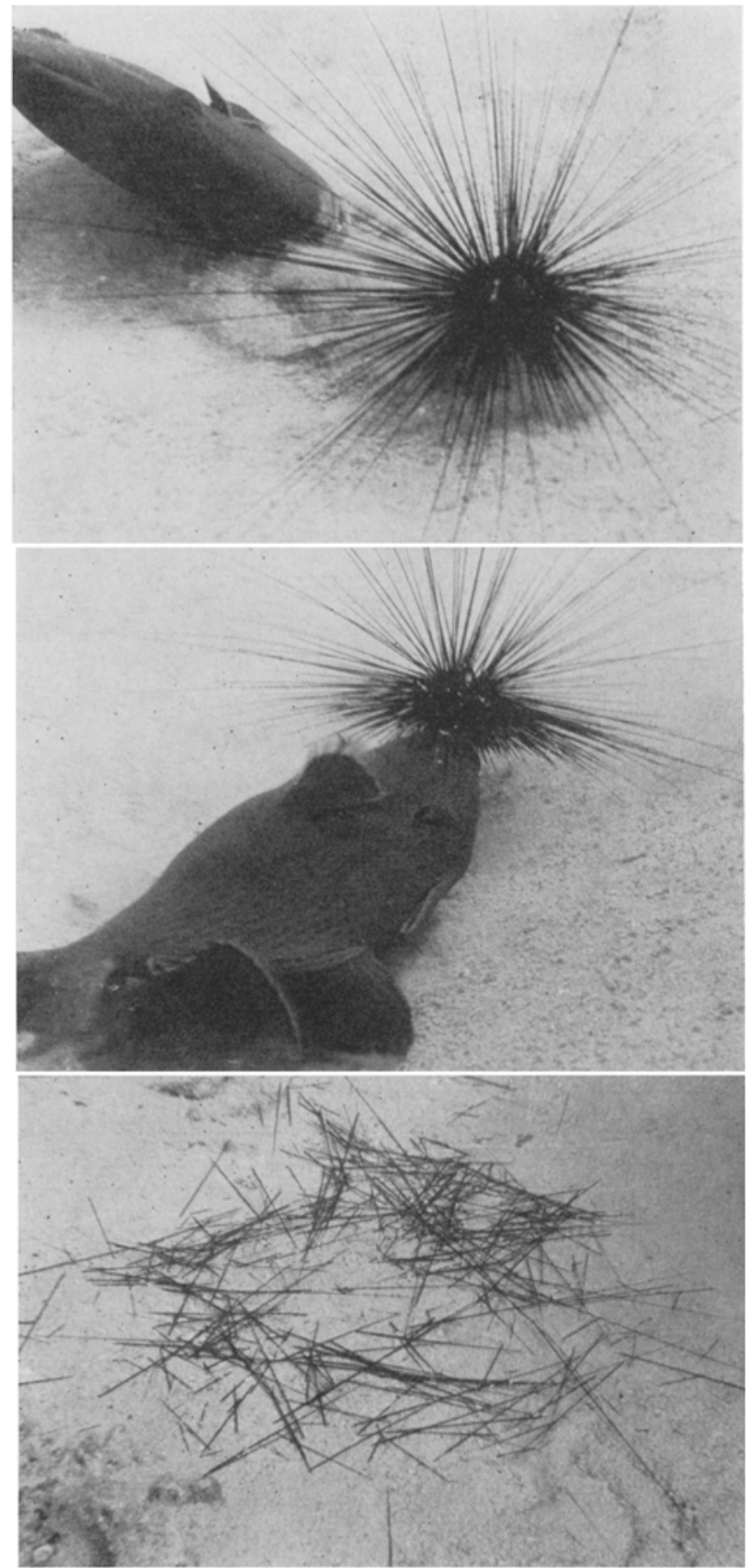

Fig. 10: Balistes fuscus feeding on sea urchins. The sea urchin is turned over by blowing (above), bitten in the oral disc (centre), and eaten, with the exception of the spines (below). (After FRICKE 1971) 
labrids and chaetodons attempt to feed on the tentacle tips, and cause the anemone to contract immediately. Such examples of enemy avoidance can be quoted in large numbers.

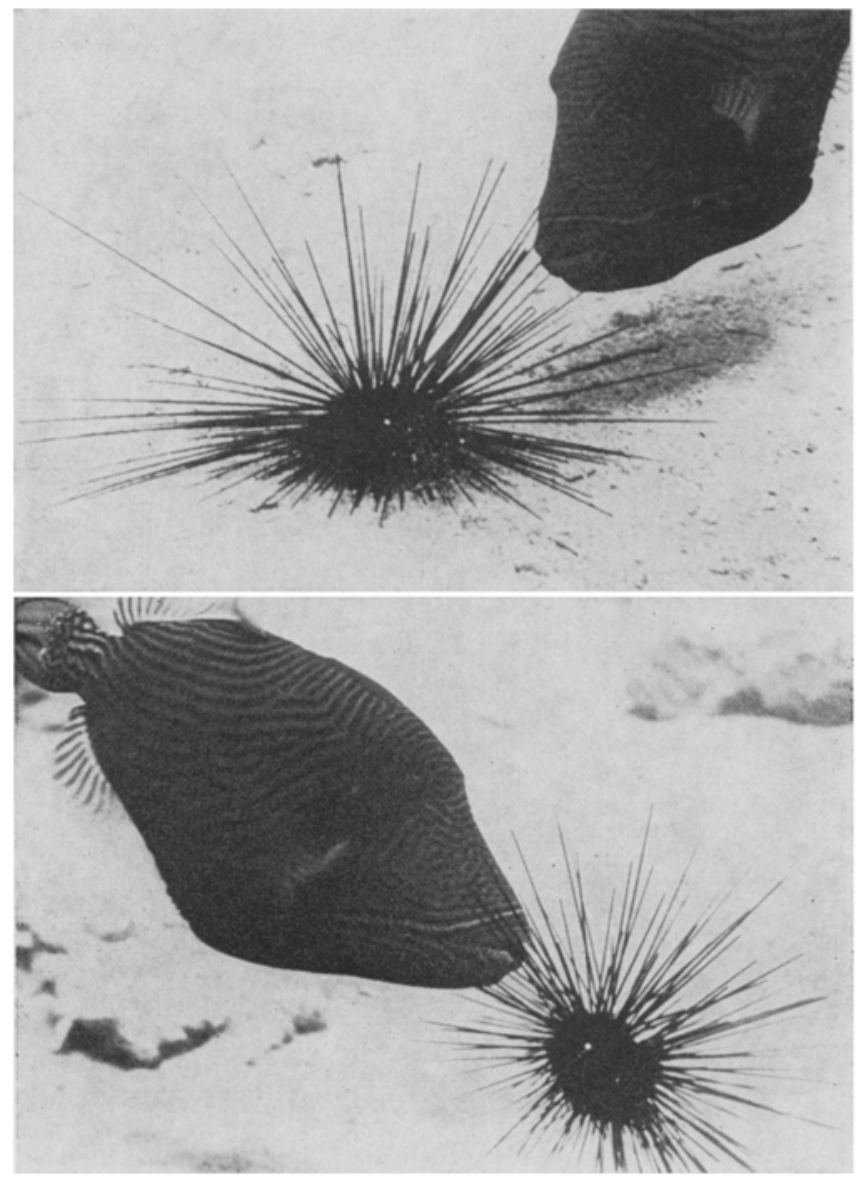

Fig. 11: Balistapus undulatus nibbles off the spines of a Diadema setosum (above) and then lifts its prey into free water (below). As the sea urchin sinks slowly back to the ground, the killing bite is delivered to its oral surface. (After FrICKE 1971)

Some fishes attack and eat even well-protected animals. Stomach-content analyses performed on fishes have revealed remains of the large sea urchin Diadema sp. (HIATT \& Strasburg 1960, Randall 1967) which must be considered well protected by its numerous long spines. In the Red Sea, I have observed 9 fish species belonging to 3 different families (Balistidae, Labridae and Lethrinidae) which (due to pre-adaptation in body structure and behaviour) are capable of avoiding the sea urchin's spines and attacking the body of the urchin (FrrCKE 1971, 1972). The methods employed by the fishes are amazing and will be illustrated briefly. 
The large triggerfish Balistes fuscus produces a stream of water by blowing until the sea urchin is turned over (Fig. 10). It kills the urchin with a bite into the oral disc where only few spines are present. A turned-over sea urchin can be killed and eaten within a few seconds. The smaller Balistapus undulatus cannot produce such a strong water current with its mouth. It slowly nibbles off the sea urchin's spines until only stumps remain. It then lifts the urchin, swims upward and finally drops it. As the sea

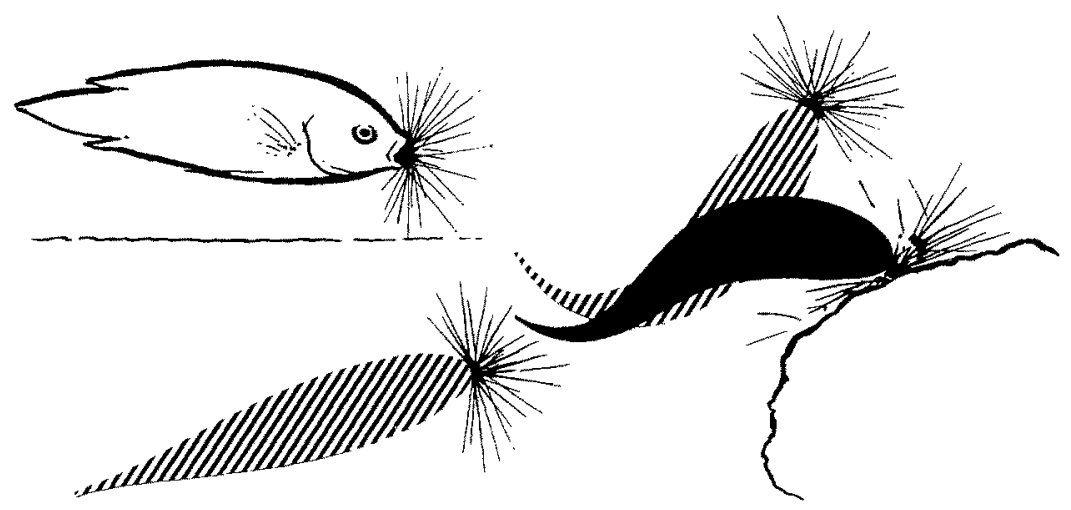

Fig. 12: Cheilinus trilobatus feeding on sea urchins. The sea urchin is smashed on a coral by lashing movements of the head. Drawings from a film by H. KACHER. (After FrICKE 1971)

urchin sinks, it is bitten in the oral disc, killed and finally eaten (Fig. 11). The labrids Cheilinus trilobatus and Coris angulata push the sea urchin over with their heads and, while doing so, bite into its body. The urchin is then carried to a stone, thrashed against it and battered to pieces by lashing movements of the fish's head; the fish then eats the pieces broken off (Fig. 12).

Labrids are territorial. Foreign conspecifics attempt to steal the prey from the labrid holding it. Owing to this, the predator often flees with the urchin to the safety of its own territory and smashes the prey there against a particular stone. This procedure represents an example of tool usage in fishes.

The snapper Letbrinus sp. and the labrid Cheilinus diagrammus exhibit less involved methods. They charge towards the sea urchin and swallow it whole, spines included.

All the fishes mentioned are not specialised sea-urchin feeders; their main food source consists of other organisms.

Choice experiments showed that sea-urchin predators are able to estimate the size of their prey relatively well. A labrid would have difficulty in biting into the body of a large sea urchin and, as a result, it selects smaller ones. The assessment of size is subject to learning. Model experiments on Balistes fuscus revealed that the prey is recognised by visual and behavioural (spine movement) characteristics.

In the species mentioned, prey capture is a convergent process; pre-adaptations in behaviour and body structure have favoured the selection of sea urchins as prey. Bali- 
stes fuscus, for example, also blows its main prey animals - crustaceans, marine snails and molluscs, out of the sand.

Sea urchins are under strong pressure from diurnal predators. What are the adaptations which the sea urchin has developed to defend itself or avoid its enemies? Diadema setosum moves its spines in a co-ordinated manner which keeps predators away. This behaviour, however, does not protect it against Balistes fuscus with its blowing technique. Spine movement is also of advantage for sea urchins which are already hidden in some crack or hole in order to protect exposed body areas.

During the day, sea urchins aggregate in groups or hide in protected places; such conditions make it difficult for the predator to capture a single individual. Despite this, Balistes fuscus has developed the ability to remove obstacles (stones, coral branches, etc.) in order to uncover a hidden sea urchin. This fish is capable of "insightful learning". It can, for example, remove sea urchins from hiding places without previous practice, or trial and error attempts.

SNYDER \& SNYder (1970) discovered that Diadema antillarum, similar to certain freshwater fishes, possess an alarm substance which instigates flight in conspecifics when an extract of sea urchin meat is introduced into the water - a physiological adaptation to predation.

It is known that Diadema antillarum is nocturnal, resulting in avoidance of diurnally active predators.

Bakus (1968) demonstrated how certain particularly poisonous nocturnal holothurians release their poison during the day, and considered this as andication that certain diurnally active fishes were predators on holothurians. I have recently observed the labrid Cheilinus trilobatus eating certain ophiuroids and these, also, were nocturnal. The alternation in activity periods of predator and prey is a widely distributed phenomenon in marine animals - a behavioural adaptation to predator avoidance. Predators and prey are, owing to the extremely high population density on the reef, driven to extreme divergences in adaptation.

\section{ADAPTATIONS IN SOCIAL BEHAVIOUR}

WICKLER (1971) has mentioned that entire drives or instinctive behaviour patterns may be considered as adaptations, whereby social behaviour and group formation is an integral part of an organism's ecological adaptation to the environment. In the case of social behaviour, the types of movement sequences which were considered adaptations to a temporary environment are usually retained when a new ecological niche is taken over. The releasing threshold for these behaviour patterns, however, is usually changed.

In the coral reef, damsel fishes (Pomacentridae) have been extremely successful in the colonisation of the environment and have shown a speciation similar to that of cichlids in African lakes. They thus lend themselves to studies on convergent evolution.

The pomacentrids either live as solitary individuals or in anonymous schools of various sizes; these usually inhabit a definite area. A few form pairs. During the breeding season, the males occupy territories, prepare a spawning area and, during this time, 
are especially aggressive. Before spawning, they attract a ripe female to the spawning site by conspicuous signal jumps. A nest, which varies in size, is formed within the spawning area; it is defended by the male against conspecifics and non-conspecifics. The male fans the eggs until the larvae hatch. These behaviour patterns have been

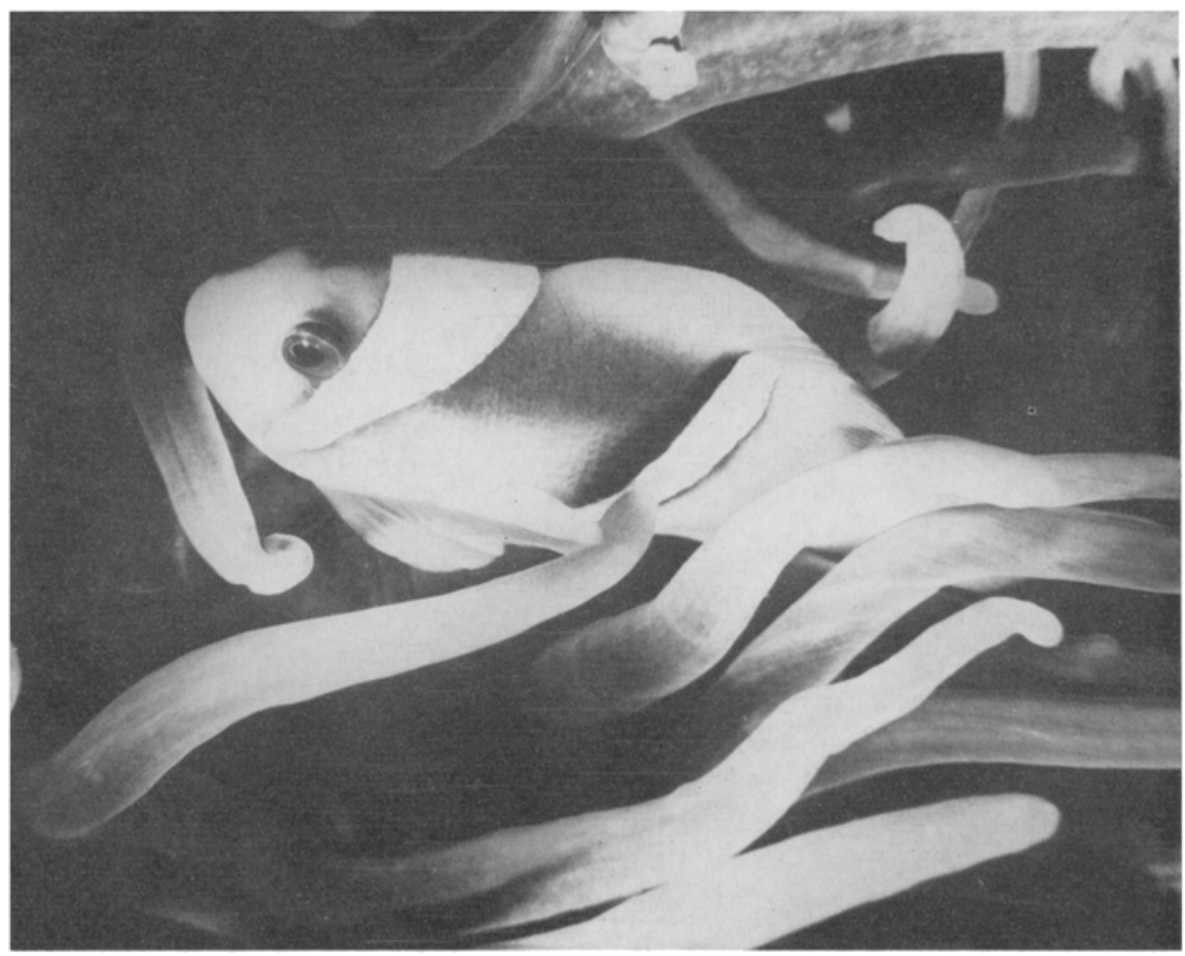

Fig. 13: The Red Sea anemone fish Ampbiprion bicinctus. Adult individuals live in permanent monogamy

found in the majority of species investigated to date (REESE 1964). The genera Amphiprion and Premnas, however, differ considerably from this pattern; these species live in symbiosis with sea anemones (cf. ALLEN 1972).

Presently, I am investigating Ampbiprion bicinctus in the Red Sea (Fig. 13). A. bicinctus and other Amphiprion species are, in contrast to the majority of pomacentrids, monogamous; the partners remain together for extremely long periods of time. Both sexes defend their anemone throughout the year; care of offspring is carried out mostly by the male. A. bicinctus is aggressive towards both conspecifics and nonconspecifics and may even attack divers (Frsfrelson 1965). Aggressive behaviour can be released at any time; it has a very low threshold. The adaptive significance of this lowering of threshold can be investigated. A. bicinctus drives away all large fish from the vicinity of the anemone, these including the anemone's predators. I could show by experiment that the anemone predator Chaetodon fasciatus is driven away from the 


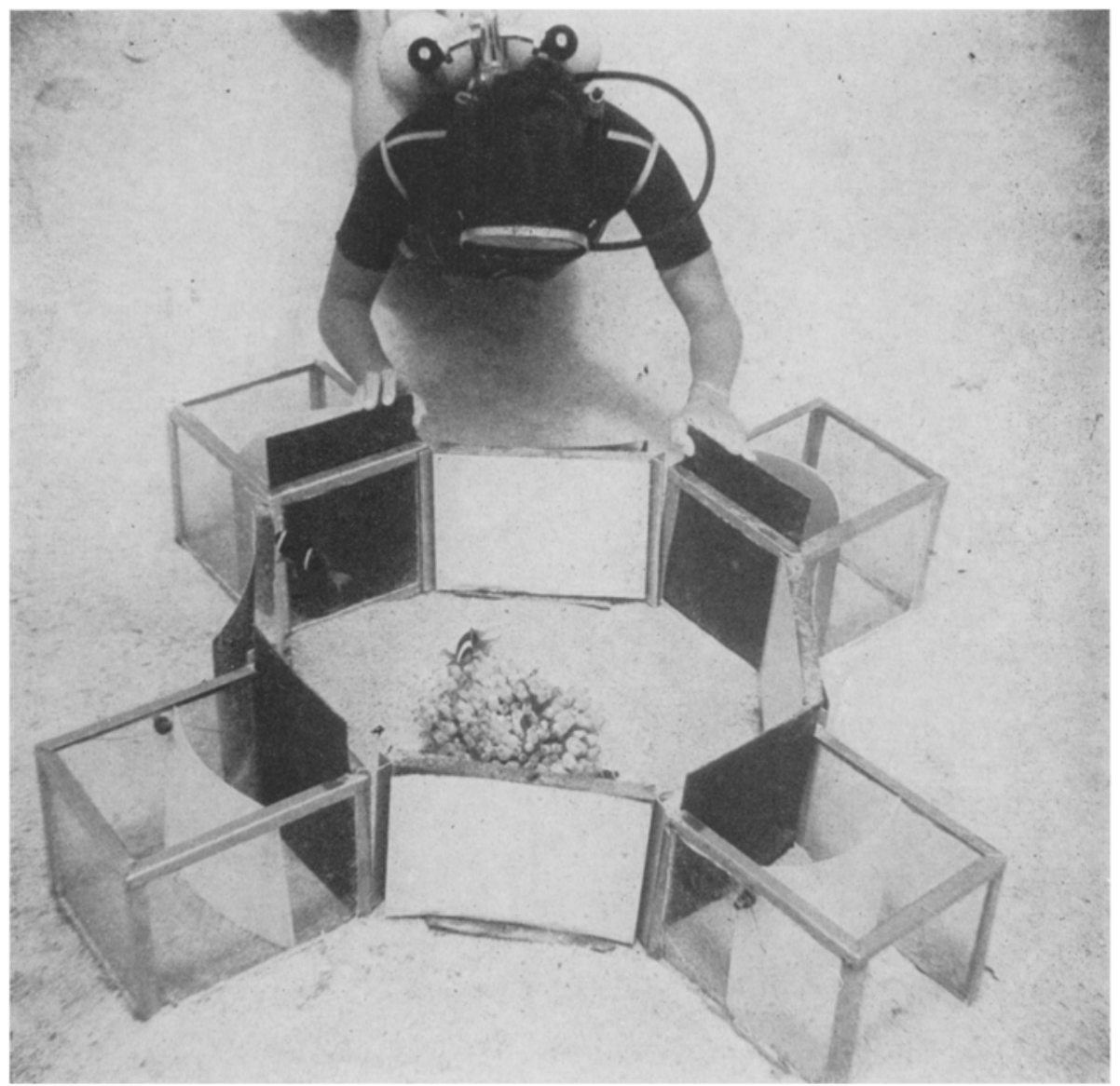

Fig. 14: Experimental set up to prove individual recognition in Ampliprion bicinctus. The central compartment contains the experimental fish; the four neighbouring compartments, three unknown individuals and the partner. The partner releases fewer or no attacks

anemone by $A$. bicinctus. Allen (1972) and others (FISHELSON 1965, MARIsCAL 1970) have made similar observations on different species. The low threshold for aggressive behaviour leads to many large fish, independent of species, being chased off. This is of advantage to the anemone in that its predators are also prevented from approaching.

This high level of aggression towards conspecifics, however, also increases the probability that these may be injured. This is partly prevented by the development of highly ritualised fighting behaviour patterns (i.e. quivering and parrying) (EnbLEdBESFELdT 1960, Allen 1972). The partner also emits - as does every other conspecific - aggression-releasing stimuli. Partners, therefore, have to perform continually "social politeness activities" to reduce the other partner's aggression, such as head-stand quivering, a submissive behaviour. Pairs of long standing have an aggression inhibition with respect to the partner. 
Partners recognise each other individually (FRICKE in press). Individual partner recognition is defined as the ability to recognise the partner from amongst a group of unknown individuals. The aggression inhibition with respect to the partner can thus be taken as an indication of individual recognition. Experiments have shown that Ampbiprion bicinctus can recognise its partner from amongst a group of 4 conspecifics (Fig. 14) and memory experiments have shown that the partner can still be recognised among other fish after a 10-day separation.

I showed by in situ experiment which of the characteristics present were important for partner recognition. Visual characteristics appear to be the most important ones. The partner is no longer recognised when its individual visual characteristics are masked. The aggression inhibition with respect to the partner then no longer exists. The advantages which individual partner recognition has in holding the pair together and the adaptive significance of monogamy for Amphiprion bicinctus are at present under investigation.

Anemone fishes are a good example of how social behaviour can change an adaptation to a specific ecological niche. The paths taken by these adaptations can be reconstructed, since a relatively large amount of information on other pomacentrids has been collected; from this, social behaviour patterns that have changed can be determined.

\section{THE ADAPTIVE VALUE OF SOCIAL STRUCTURES}

Social systems and social behaviour depend on the environment and should be considered under the aspect of adaptation. Correlations between social systems and social behaviour are of interest to ecological-sociological ethology. These should lead - as I have previously mentioned - to a comparison between general rules which are independent of the relationships between animal species. Experiments of this type are now in progress with regard to the larger group-living animals of the African plains. WICKLER (1971) is attempting to investigate the problem of duo-groups in monogamous animals of various species. Two questions arise from these investigations: (a) which mechanisms keep the group together? (b) What is the selective advantage of one group social system with respect to others from the point of view of the animal concerned?

In the coral reef, related species of butterfly fishes (Chaetodontidae) show a rather uniform type of social structure. The majority of fishes live in pairs (Fig. 15). This behaviour is so conspicuous that it must be based on an ecological adaptation. To enable the social structure of this group to be more readily understood, its ecology must be more thoroughly studied. Butterfly fishes have become generally known during the past few years owing to LoRENz' aggression hypothesis, which suggests that their bright body colours represent an adaptation to aggression release (LorENz 1962, 1963). The more brightly coloured the species, the more aggressive it is. Aggression is directed only against conspecifics which occupy the same ecological niche. Butterfly fishes are territorial, and territoriality and aggression are, according to LoRENZ, of great selective advantage. Aggression is shown by the individuals within the space available for sur- 
vival; a feeding territory is thus established and maintained by such territorial behaviour.

Stomach-content analyses by HiatT \& STRASBURg (1966), amongst others, have shown that chaetodons feed on a whole range of animal and plant foods. Fragments of coral polyps are commonly present. Food of this type is available in abundance on the coral reef, so that feeding competition should not be present in this group of fish. Despite this, RANDALL \& HARTMANN (1968) have shown that slight preferences for certain types of food are present in certain Caribbean species. Holocantbus tricolor, for example, feeds on sponges with bitter, poisonous skeletal elements, which are avoided

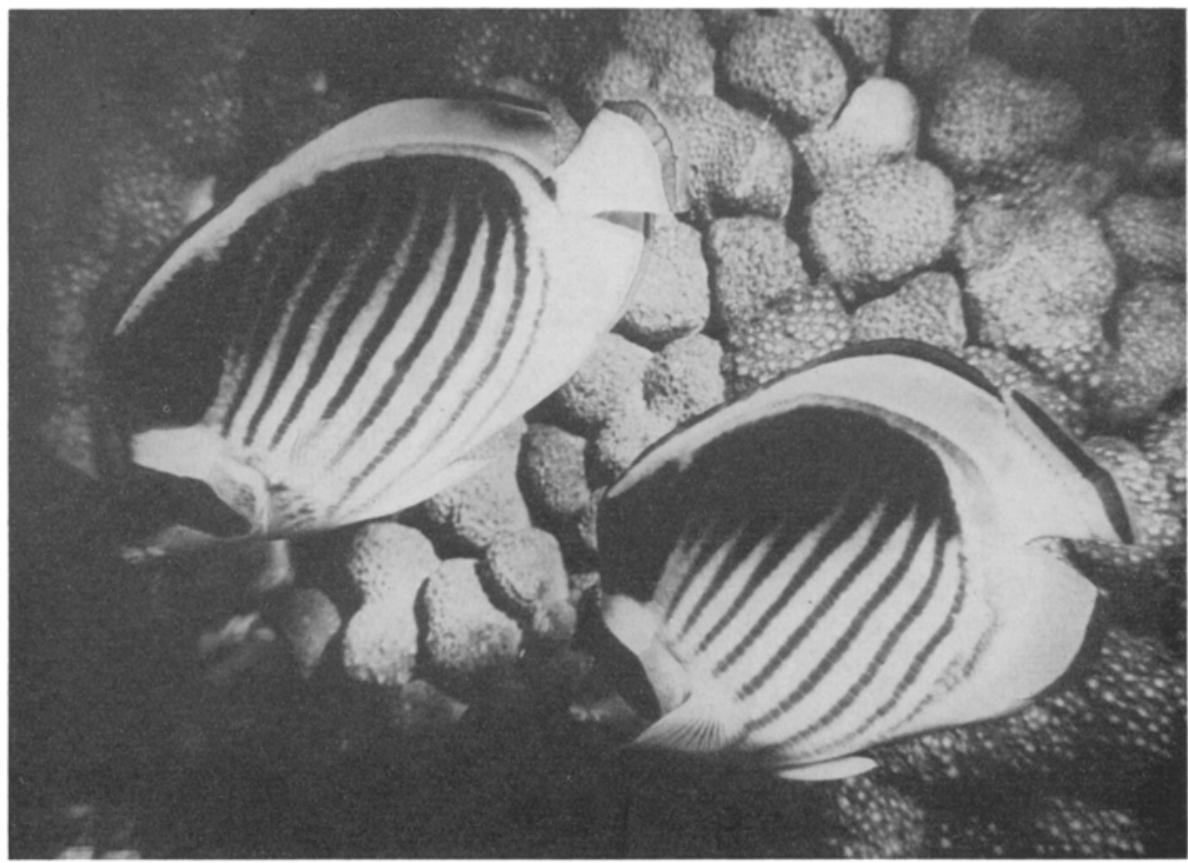

Fig. 15: The majority of chaetodons (here Chaetadon fasciatus) from the Red Sea swim in pairs. Grouping occurs on occasion; its function is unknown

by other species. I believe that territorial behaviour - apart from the defence of a feeding area - is important for providing a safe retreat within a known area. Butterfly fishes have an amazingly accurate topographical memory. Good knowledge of the surroundings increases the chances of survival under the conditions of increased predation pressure in the reef.

Territorial behaviour has been proved by marking the fishes (Fig. 16). Ecological investigations have shown that certain butterfly fishes are distributed along different areas of the reef face. The majority of species live in shallow water; Heniochus acuminatus, however, can be found at depths of $50 \mathrm{~m}$, and Chatodon falcifer has even been observed from submarines at $150 \mathrm{~m}$ (FREIHOFER 1966). Apart from preference for a certain depth, habitat preference may be present. Megaprotodon trifascialis lives 
mainly in the vicinity of table corals Acropora sp. C. kleinii prefers rocky areas covered with a'gae. Other species are universalists; C. chrysurus is present in all reef zones in the Gulf of Aqaba (Israel) and can even be found on sandy, open bottoms. $C$. austriacus, however, always remains close to the reef. In situ investigations have shown that juvenile and adult fish inhabit different reef zones on the Comore Island Anjouan (Fig. 17).

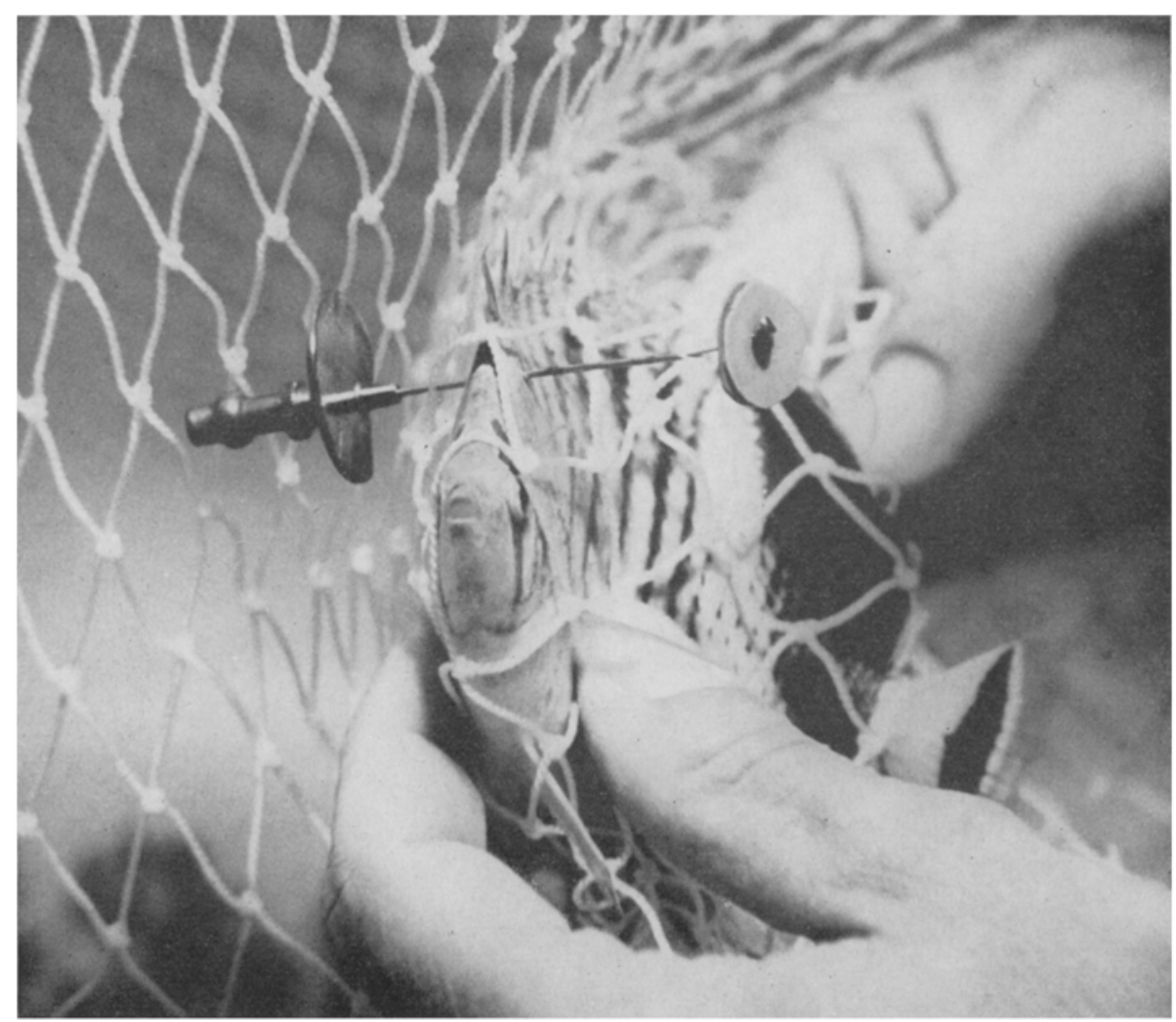

Fig. 16: Marking of a Chaetodon cbrysurus. An injection needle is inserted through the dorsal musculature and a silver wire passed through it. A plastic marking tag is attached to the end of the wire (method of ReINBoth)

We were able to prove that butterfly fishes in the reef are ecologically specialised in various ways. Counts made on different reef zones of the Red Sea and of the Indian Ocean revealed that between 8 and 14 species can live sympatrically in the same zone. Though interbreeding with closely related species is genetically possible, it does not seem to occur. Hybrids are usually less well adapted and crossing could thus present a danger for the adaptive specialisations which have developed. What are the mechanisms for successful reproductive isolation?

I assume that the bright poster colours can be considered as species-recognition signals. Mating with other species is less probable when species are able to distinguish 
between one another. A selection pressure for the greatest possible differences appears to be present. Despite this, mistakes can be made with regard to species of very similar coloration. I put forward the hypothesis that the social structure - a monogamous pair - is an additional mechanism for butterfly fishes, preventing crossing between different species and thus being an example of reproductive isolation. The adaptive significance of this social system would thus be to prevent the species from being adulterated by foreign genetic influences. Continual monogamy could therefore have been evolved under conditions of high species density.

WICKLER (1969) showed that pairing, reproduction, pair formation and care of offspring are not necessarily combined. For instance, monogamy does not have to fulfil the function of enabling the offspring to be more easily and more safely raised. Observations to date have indicated that chaetodons show no brood care; hence their monogamy may have another function.

Interspecific pairing is more possible at the periphery of a species distribution area where population density is low. Chances of encountering a conspecific are reduced in such zones. Observations in the Red Sea have shown that the relationship of the number of pairs to number of single fish decreases sharply with population density. In sparsely populated areas, pairs occur much more commonly.

Continual monogamy could thus prevent pairing with foreign species, expecially in such areas. Marking experiments have shown that the pair partner does not change, at least not over a period of 3 years.

It may be assumed that the partners of a pair show synchronisation in their reproductive cycles. It would be of advantage to retain the known, synchronised partner and to be able to distinguish this from other foreign conspecifics. Observations have shown that the pair partner can be distinguished from other individuals. This individual recognition is an intraspecific safety device preventing mistakes in partner choice.

Juvenile butterfly fishes present a special problem. The majority of these differ in coloration from the adults or have a conspicuous pattern of round spots (eyespots) (Fig. 18). They start to develop adult coloration during ontogeny. I believe that these juveniles mask their species membership. In this way, they do not induce attacks from adults and can live within the adults' territories. Apart from this, the juveniles of some species inhabit other reef zones in which the adults are often not present (Fig. 17). Juveniles differ in their ecological specialisation; this fact indicates how differences in ecological specialisation may result in the development of different colour patterns. Even the eyespots appear to be a means of species camouflage. Eyespots are more common in juveniles which are similar in coloration to the adults (e.g. Chaetodon cbrysurus, C. fasciatus, C. lunula). In C. capsitratus, adults also possess an eyespot; juveniles, however, two. Even the juveniles of Amphiprion bicinctus, which may possess one or two eyespots, are not attacked by conspecifics.

I believe that the examples cited provide sufficient evidence to indicate the selective advantages of continual monogamy for chaetodons in the reef. Poster colours and continual monogamy appear to allow several sympatric species to exist next to one another. It is still an open question, however, how this pronounced degree of speciation in the butterfly fishes has come about.

I hope, in the future, to be able to describe and analyse the social behaviour and 

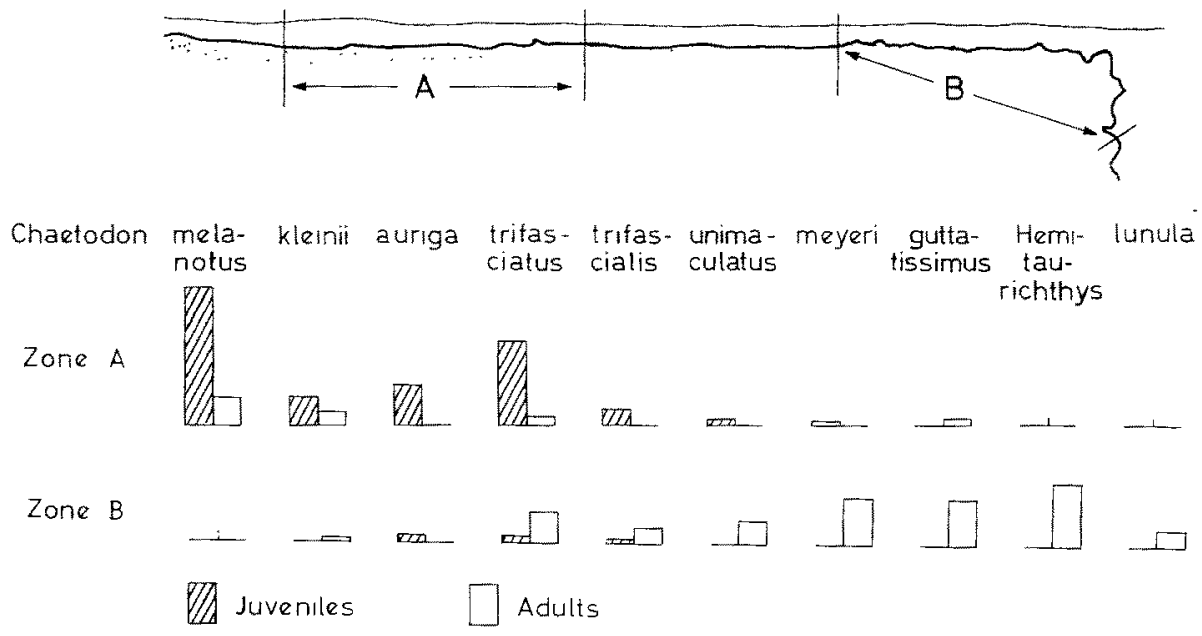

Fig. 17: Distribution of juvenile and adult butterfly fish (Chaetodontidae) in different reef areas (A and B). Mutsamuda on Anjouan (October, 1969). Block diagrams represent percentages of total Chaetodon population. Zone A $\mathrm{n}=154$, Zone $\mathrm{B} n=353$. Block size for symbols, jureniles or adults, represents $15 \%$ of the total population
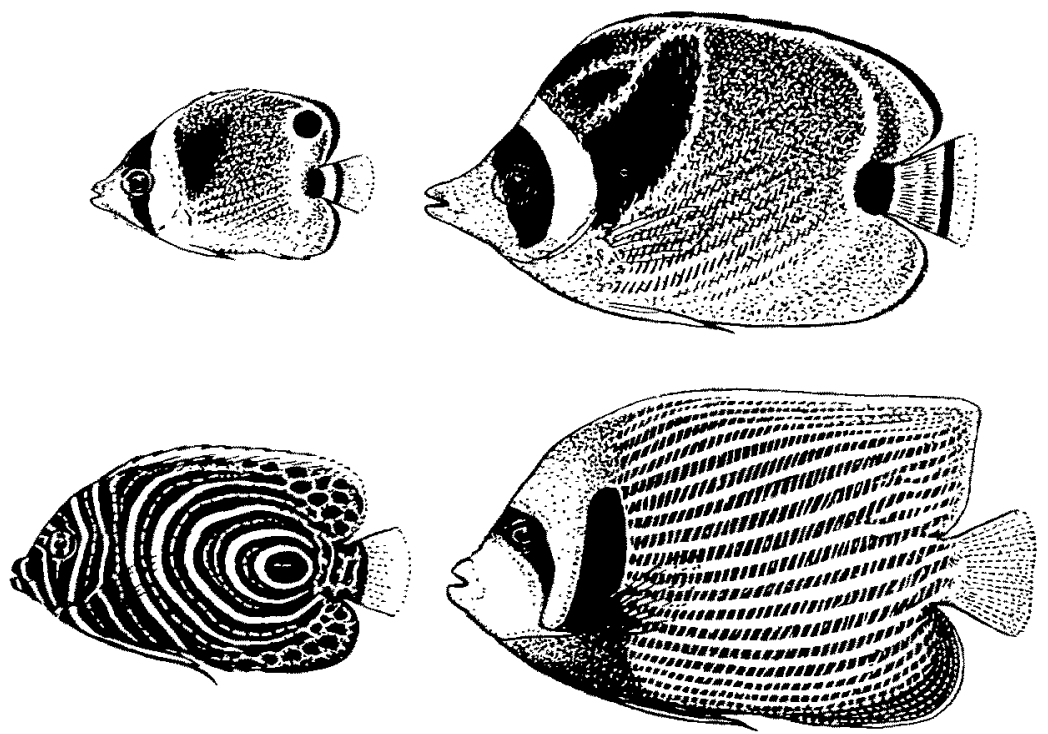

Fig. 18: Differences in coloration between juvenile (left) and adults (right) butterfly fish. Above: Chaetodon lunula, below: Pomacanthus imperator

social structure of reef inhabitants quantitatively. The main object of such studies will not only be to assess co-operation between behaviour and ecology by comparison but, at the same time, to conduct experiments to determine functional details of social behaviour and social structure. 


\section{SUMMARY}

1. An animal's behaviour represents part of its ecological adaptation to the environment (inanimate surroundings, food, enemies, conspecifics and animals of other species).

2. In the case of feeding, plankton filter feeders are referred to which exhibit identical activity periods, the same choice of habitats and comparable types of movement during feeding; this parallelism is interpreted as adaptation to the mode of nourishment. Similarity in feeding behaviour is indicative of convergent development. In ophiurids, water-current filtration appears to be an ancient phylogenetic characteristic. It is present in numerous species, indicating that this type of behaviour is homologous. Garden eels (Heterocongridae) are also plankton feeders. Their mode of feeding reveals analogies to that of marine benthonic invertebrates. Fishes which feed on sea urchins exemplify adaptations to prey capture and enemy avoidance. Sea urchins have developed adaptive protections against being preyed upon; these tend to result in escaping potential predators or preventing contact with them. Nocturnal activity appears to be an adaptation leading to enemy avoidance. Behaviour patterns of predators are described and compared. Preying on sea urchins appears to be a convergent development based on pre-adaptations in behaviour patterns and morphological structures. Particular adaptations are always based on characteristics already present.

3. Social behaviour is also part of the ecological adaptation of an animal to its environment. The social behaviour of the Pomacentridae is cited as example. Studies on the monogamous anemone fish Amphiprion bicinctus showed that its well-developed aggressive behaviour to both conspecifics and non-conspecifics can be easily released. $A$. bicinctus drives away all large fishes from its territory, including predators of the anemone. Well-developed intraspecific aggression necessitates effective aggression inhibition with respect to the sexual partner. The potential aggression of one member of the pair must be continually neutralised by submissive behaviour on the part of its mate. Members of a pair recognise each other individually. In situ experiments showed that they recognise the partner mainly through visual characteristics. Comparison of social behaviour in A. bicinctus with that of other pomacentrids should reveal adaptations to life in the narrow confines of the sea anemone.

4. Butterfly fishes (Chaetodontidae), which live in coral reefs, are monogamous. Their social structure and conspicuous coloration are considered as adaptations to extremely high species densities (up to 14 sympatric species), which are ecologically specialised in various ways. Continual monogamy and conspicuous coloration enable sympatric species to live in the same environment. The difference in coloration between the juveniles and adults is considered species camouflage, a mechanism enabling the juveniles to survive and reach maturity within the home range of the adults. 


\section{LITERATURE CITED}

Allen, G. R., 1972. The anemone fishes. T.F.H. Publs, Neptune City, N.Y., 288 p.

Bakus, G. J, 1968. Defensive mechanisms and ecology of some tropical holothurians. Mar. Biol. 2, 23-32.

Casmmr, M. \& Fricke, H. W., 1971. Zur Funktion, Morphologie und Histochemie der Schwanzdrüse bei Röhrenaalen (Pisces, Apodes, Heterocongridae). Mar. Biol. 9, 339--346.

Castle, P. H. J., 1967. Heterocongrine eels in the Southwest Pacific. Rec. Dom. Mus. Wellington 6, 5-12.

Clarke, E., 1972. The Red Seas garden of eels. Natn. geogr. Mag. 142, 724-735.

Davis, W., 1966. Observations on the biology of the ophiuroid Astrophyton muricatum. Bull. mar. Sci. 16, 435-444.

EnbL-EIBEsFeldT, J., 1960. Beobachtungen und Versuche an Anemonenfischen. Z. Tierpsychol. $17,1-10$.

Fisherson, L., 1965. Observations and experiments on the Red Sea anemones and their symbiotic fish Amphiprion bicinctus. Contr. Knowl. Red Sea 39, 3-16.

Freihofer, W. C., 1966. New distributional records of the butterflyfish Chaetodon falcifer. Stanford ichthyol. Bull. 8, 207.

Fricke, H. W., 1966. Ner Nahrungserwerb des Gorgonenhauptes Astroboa nuda. Natur Mus., Frankf. 96, 501-510.

- 1968. Beiträge zur Biologie der Gorgonenhäupter Astropbyton muricatum und Astroboa nuda. Math. nat. Diss., FU Berlin. 107 pp.

- 1969. Biologie et comportement de Gorgasia sillneri (KLAUsewrTZ) et Taenioconger hassi (Klausewitz, Erbl-Erbesfeldt) (Teleosteen). C. r. hebd. Séanc. Acad. Sci., Paris 269, $1678-1680$.

- 1970a. Neue kriechende Ctenophoren der Gattung Coeloplana aus Madagaskar. Mar. Biol. $5,225-238$.

- 1970b. Contribution à l'étude des ctenophores platyctenides de Madagaskar - Ctenoplana (Diploctena s. gen.) neritica n. sp. et Coeloplana (Bentboplana n. s. gen.) meteoris (THIEL). Cah. Biol. mar. 12, 57-75.

- 1970c. Beobachtungen über das Verhalten und Lebensweise des im Sand lebenden Schlangensternes Amphioplus sp. Helgoländer wiss. Meeresunters. 21, 124-133.

- 1970d. Okologische und verhaltensbiologische Beobachtungen an den Röhrenaalen Gorgasiat sillneri und Taenioconger hassi. Z. Tierpsychol. 27, 1076-1099.

- 1971. Fische als Feinde tropischer Seeigel. Mar. Biol. 9, 328-338.

- 1972. Korallenmeer - Verhaltensforschung am tropischen Riff. Belser, Stuttgart, 223 pp.

- Individual recognition: field studies on Amphiprion bicinctus (in press).

Hiatt, R. W. \& Strasburg, D. W., 1960. Ecological relationships of the fish fauna on coral reefs of the Marshall Islands. Ecol. Monogr. 30, 65-127.

Klausewitz, W. \& Erbl-EibesfeldT, I., 1959. Neue Röhrenaale von den Malediven und Nikobaren. Senckenberg. biol. 40, 135-153.

Lorenz, K., 1962. The function of color in corall reef fishes. Proc. R. Instn Gt Br. 39, 282-296.

- 1963. Das sogenannte Böse. Borotha-Schoeler, Wien, 391 pp.

MAGnus, D. B. E., 1963a. Der Federstern Heterometra savigny im Roten Meer. Natur Mus., Frankf. 93, 355-368.

- 1963b. Uber das Abweiden der Flutwasseroberfläche durch den Schlangenstern Opbiocoma scolopendrina. Zool. Anz. (Suppl.) 26, 471-481.

- 1964a. Wasserströmung und Nahrungserwerb bei Stachelhäutern des Roten Meeres. Ber. phys.-med. Ges. Würzb. 71, 128-141.

- 1964b. Gezeitenströmung und Nahrungsfiltration bei Ophiouroiden und Crinoiden. Helgoländer wiss. Meeresunters. 10, 104-117.

Mariscal, R. N., 1970. The nature of the symbiosis between Indo-Pacific anemone fishes and sea anemones. Mar. Biol. 6, 58-65. 
Randall, J. E., 1967. Food habits of reef fishes of the West Indies. Stud. trop. Oceanogr. 5, 665-847.

- \& Hartman, W. D., 1968. Sponge-feeding fishes of the West Indies. Mar. Biol. 1, 216-225.

ReEse, E. S., 1964. Ethology and marine zoology. Oceanogr. mar. Biol. 2, 455-488.

SNYDER, N. \& SNYDER, H., 1970. Alarm response of Diadema antillarum. Science, N.Y. 168, 276-278.

Tsurnamal, M. \& Marder, J., 1966. Observations on the basket star Astroboa nuda on coral reefs at Elat (Gulf of Aquaba). Israel J1 Zool. 15, 9-17.

Wickler, W., 1959. Die ökologische Anpassung als ethologisches Problem. Naturwissenschaften 46, 505-509.

- 1961. Okologie und Stammesgeschichte von Verhaltensweisen. Fortschr. Zool. 13, 303-365.

- 1967. Vergleichende Verhaltensforschung und Phylogenetik. In: Die Evolution der Organismen. Hrsg. von G. Heberer. Fỉscher, Stuttgart, 1, 420-508.

- 1969. Sind wir Sünder? Droemer, München, 247 pp.

- 1971. Soziales Verhalten als ökologische Anpassung. Verh. dt. zool. Ges. 64, 291-304.

Author's address: Dr. H. W. FrIcke

Max-Plandk-Institut für Verhaltensphysiologie

8131 Seewiesen

Federal Republic of Germany 